\title{
Epigallocatechin-3-gallate inhibits proliferation and migration of human colon cancer SW620 cells in vitro
}

\author{
Fang ZHOU ${ }^{1,2}$, Hong ZHOU ${ }^{2, *}$, Ting WANG ${ }^{2}$, Yuan $\mathrm{MU}^{2}$, Biao $\mathrm{WU}^{2}$, Dong-lin $\mathrm{GUO}^{2}$, Xian-mei ZHANG ${ }^{2}$, Ying WU ${ }^{2}$ \\ ${ }^{1}$ Department of Clinical Laboratory, Jiangsu Province Rongjun Hospital, Wuxi 214035, China; ${ }^{2}$ Department of Clinical Laboratory and \\ Hematology, Jiangsu University School of Medicine, Zhenjiang 212013, China
}

\begin{abstract}
Aim: Epigallocatechin-3-gallate (EGCG) is the major polyphenolic constituent in green tea. The aim of this study is to investigate the effects of EGCG on proliferation and migration of the human colon cancer SW620 cells.

Methods: Proliferation and migration of SW620 cells were induced by the protease-activated receptor 2-agonist peptide (PAR2-AP, $100 \mu \mathrm{mol} / \mathrm{L}$ ) or factor VIla (10 nmol/L), and analyzed using MTT and Transwell assays, respectively. The cellular cytoskeleton was stained with rhodamine-conjugated phalloidin and examined with a laser scanning confocal fluorescence microscope. The expression of caspase-7, tissue factor (TF) and matrix metalloproteinase (MMP)-9 in the cells was examined using QT-PCR, ELISA and Western blot assays. The activation of extracellular signal-regulated kinase 1 and 2 (ERK1/2) and nuclear factor-kappa B (NF-kB) signaling pathways was analyzed with Western blot.

Results: Both PAR2-AP and factor VIla promoted SW620 cell proliferation and migration, and caused cytoskeleton reorganization (increased filopodia and pseudopodia). Pretreatment with EGCG $(25,50,75$, and $100 \mu \mathrm{g} / \mathrm{mL})$ dose-dependently blocked the cell proliferation and migration induced by PAR2-AP or factor VIla. EGCG (100 $\mu \mathrm{g} / \mathrm{mL})$ prevented the cytoskeleton changes induced by PAR2-AP or factor VIla. EGCG $(100 \mu \mathrm{g} / \mathrm{mL})$ counteracted the down-regulation of caspase-7 expression and up-regulation of TF and MMP-9 expression in the cells treated with PAR2-AP or factor VIla. Furthermore, it blocked the activation of ERK1/2 and NF-KB (p65/RelA) induced by PAR2-AP or factor VIla.

Conclusion: EGCG blocks the proliferation and migration of SW620 cells induced by PAR2-AP and factor VIla via inhibition of the ERK1/2 and NF-KB pathways. The compound may serve as a preventive and therapeutic agent for colon cancers.
\end{abstract}

Keywords: epigallocatechin-3-gallate; polyphenol; protease-activated receptor 2; factor VIla; tissue factor; colon cancer; ERK1/2; NF-KB

Acta Pharmacologica Sinica (2012) 33: 120-126; doi: 10.1038/aps.2011.139; published online 21 Nov 2011

\section{Introduction}

Recently, tissue factor (TF) has attracted considerable attention as a receptor capable of mediating intracellular signals closely involved in metastasis, angiogenesis and tumor growth ${ }^{[1]}$. TF is expressed in a wide variety of malignancies ${ }^{[2]}$ and can induce a variety of non-coagulant cellular responses related to angiogenesis, metastasis, tumor growth, and cell migration ${ }^{[3,4]}$. It has been found that TF binding to factor VII (hereafter factor VII) or factor VIIa can trigger cell signal transduction via activation of protease-activated receptor 2 (PAR2) ${ }^{[5]}$. The activation of PAR2 induced by the TF/factor VIIa complex may contribute to the malignant behavior of certain cancer cells ${ }^{[6]}$.

PAR2 is a G-protein-coupled receptor activated by prote-

\footnotetext{
* To whom correspondence should be addressed.

E-mail hongzhou@ujs.edu.cn

Received 2011-07-06 Accepted 2011-09-22
}

olytic cleavage of its amino terminal domain. Experimentally, PARs can also be activated by synthetic peptides [referred to as an agonist peptide (AP)] that mimic the neo-amino terminus of the cleaved receptors. Specific PAR-APs are important tools for investigating the roles of PAR activation ${ }^{[7]}$. In a previous study, we observed that TF and PAR2 are highly expressed in the colon cancer cell line SW620 ${ }^{[8]}$. Treatment with factor VIIa $(10 \mathrm{nmol} / \mathrm{L})$ induced SW620 cell proliferation and migration. The effects of factor VIIa on cells are similar to that of the PAR2 agonist peptide, PAR2-AP, and could be inhibited by anti-TF or anti-PAR2 antibodies. Furthermore, some intracellular signaling molecules were activated in these processes $^{[9]}$. These results led us to hypothesize that there is a TF/factor VIIa/PAR2 axis in SW620 cells, and this axis might be a potential therapeutic target for colon cancers.

Epigallocatechin-3-gallate (EGCG), the major polyphenolic constituent in green tea, is well known to possess remarkable 
cancer chemo-preventive activity and therapeutic potential against various cancers due to its ability to inhibit cell growth, arrest cell cycle and induce apoptosis in some human carcinoma cells. One mechanism by which EGCG exerts its antitumor effects is through the inhibition of cell signaling associated with tumor cell proliferation, apoptosis, invasion and metastasis $^{[10,11]}$.

Although it has been known for several years that EGCG has potent anticancer effects, whether or not it can affect TF/ factor VIIa/PAR2 axis-mediated proliferation and migration of SW620 cells remains unclear. In the current study, we investigated whether EGCG is capable of blocking the stimulating effects of the TF/factor VIIa/PAR2 axis on SW620 cells and the possible mechanisms involved in this process.

\section{Materials and methods Materials}

Leibovitz's L-15 medium and fetal bovine serum (FBS) were obtained from Gibco BRL (Grand Island, NY, USA). EGCG (purity $>98 \%$ ) was purchased from Sigma (St Louis, MO, USA). The PAR2 agonist (SLIGKV-NH $\mathrm{N}_{2}$ PAR2-AP) was synthesized by Proteintech Group Inc (Wuhan, China). Recombinant human factor VIIa was obtained from Novo Nordisk (Maaloev, Denmark). All reagents (EGCG, PAR2-AP, and factor VIIa) were dissolved in distilled water and then diluted in medium. Trizol and RT-PCR reagents were purchased from Invitrogen (Carlsbad, CA, USA). MMP-9 ELISA assay kits were purchased from R\&D Systems, Inc (Minneapolis, MN, USA). TF activity assay kits (Actichrome ${ }^{\mathrm{TM}} \mathrm{TF}$ ) were purchased from American Diagnostica, Inc (Greenwich, CT, USA). Polyclonal anti-caspase-7, anti-ERK1/2 and anti-NF-kB (p65) antibodies were obtained from Cell Signaling Technology (Beverly, MA, USA). Polyclonal anti-histone H3 antibody was purchased from Biosynthesis Biotechnology Co, Ltd (Beijing, China). Nuclear and cytoplasmic extraction kits were purchased from KeyGen Biotech Co, Ltd (Nanjing, China). All other chemicals and reagents used in the experiments were commercially available.

\section{Cell lines and cell culture}

The human colon cancer cell line SW620 was obtained from Shanghai Institutes for Biological Sciences (Shanghai, China). The cells were cultured in Leibovitz's L-15 medium supplemented with $10 \%$ FBS. The cells were maintained at $37^{\circ} \mathrm{C}$ in a humidified atmosphere of $5 \% \mathrm{CO}_{2}$ and were deprived of serum for $16 \mathrm{~h}$ before they were used in the experiments. All of the experimental data were obtained from cells passaged between 3 and 10 times.

\section{Cell proliferation assay}

The SW620 cells were seeded in 96-well plates at $5 \times 10^{4}$ cells per well and grown to $70 \%$ confluence in culture medium. The cells were pretreated with various concentrations of EGCG $(0,25,50,75$, and $100 \mu \mathrm{g} / \mathrm{mL})$ for $15 \mathrm{~min}$ and then stimulated with PAR2-AP $(100 \mu \mathrm{mol} / \mathrm{L})$ or factor VIIa $(10 \mathrm{nmol} / \mathrm{L})$ in the presence of EGCG for $24 \mathrm{~h}$. Then, $20 \mu \mathrm{L}$ of MTT solu- tion (5 mg/mL in PBS) was added to each well, and the cells were incubated for another $4 \mathrm{~h}$ at $37^{\circ} \mathrm{C}$. Finally, the culture media were removed and the cells were solubilized with 100 $\mu \mathrm{L}$ dimethylsulfoxide (DMSO), and the absorbance of the cells was measured at $490 \mathrm{~nm}$ using a microtiter plate photometer (BioTek, USA).

\section{Cell migration assay}

Cell migration assays were performed using modified Boyden chambers with a $65 \mu \mathrm{m}$ diameter and a porous $(8 \mu \mathrm{m})$ polycarbonate membrane separating the two chambers (Transwell, Corning Inc, USA). The cells were harvested by brief exposure to trypsin/EDTA and neutralized with Leibovitz's L-15 medium. The cells were washed and resuspended in medium with $0.1 \%$ bovine serum albumin (BSA) in an adequate concentration. At the indicated times, cells $\left(1.0 \times 10^{5}\right.$ in $\left.100 \mu \mathrm{L}\right)$ were incubated with EGCG $(100 \mu \mathrm{g} / \mathrm{mL})$ for $15 \mathrm{~min}$ at $37^{\circ} \mathrm{C}$, then placed in the upper compartments in the continued presence of EGCG. Cells were placed in the upper compartment of the migration chamber with PAR2-AP $(100 \mu \mathrm{mol} / \mathrm{L})$ or factor VIIa $(10 \mathrm{nmol} / \mathrm{L})$ in both the upper and lower compartments. The cells without any agonists or inhibitors in the assay were used as a control. After $8 \mathrm{~h}$ of incubation, the cells that had migrated through the pores to the lower side of membrane were fixed with methanol and stained with Giemsa. The number of cells was counted in five randomly chosen fields using light microscopy $(\times 200)$. For each triplicate, the number of cells in ten high power fields was determined, and the counts were averaged.

\section{Cellular cytoskeleton detection}

The SW620 cells were placed in 24-well culture dishes at a density of $3 \times 10^{4}$ cells per well in culture medium containing $10 \% \mathrm{FBS}$ at $37^{\circ} \mathrm{C}$ in $5 \% \mathrm{CO}_{2}$. After $12 \mathrm{~h}$, the cells were serumstarved for $16 \mathrm{~h}$ prior to stimulation with PAR2-AP (100 $\mu \mathrm{mol} / \mathrm{L})$ or factor VIIa $(10 \mathrm{nmol} / \mathrm{L})$ for $1 \mathrm{~h}$. The cells in some wells were pretreated with EGCG $(100 \mu \mathrm{g} / \mathrm{mL})$ for $15 \mathrm{~min}$ as described above. Then, the cells were fixed on glass coverslips with $4 \%$ paraformaldehyde and washed with PBS three times. The DNA was stained with Hoechst 33342 (Sigma), and the actin cytoskeleton was stained with rhodamine-conjugated phalloidin (Sigma). The samples were observed under a laser scanning confocal fluorescence microscope (Carl Zeiss, Germany).

\section{Quantitative real-time PCR analysis}

The SW620 cells were seeded at $1 \times 10^{6}$ cells $/ \mathrm{mL}$ into 6-well plates and serum-starved for $16 \mathrm{~h}$ prior to stimulation with PAR2-AP $(100 \mu \mathrm{mol} / \mathrm{L})$ or factor VIIa $(10 \mathrm{nmol} / \mathrm{L})$ for $2 \mathrm{~h}$. The cells in some wells were pretreated with EGCG (100 $\mu \mathrm{g} / \mathrm{mL}$ ) for $15 \mathrm{~min}$. Then, the total cellular RNA was isolated, and first-strand cDNA was synthesized using SuperScript II reverse transcriptase (Life Technologies). Finally, Q-PCR was performed using a Rotor-Gene 2000 (Corbett Research, Australia). The caspase-7 forward primer was 5'-TGACCTATCCTGCCCTCA-3', and the reverse primer was 5'-TCTCCTGC- 
CTCACTGTCC-3'. Primers for the control housekeeping gene $\beta$-actin were 5'-CACGAAACTACCTTCAACTCC-3' (forward) and 5'-CATACTCCTGCTTGCTGATC-3' (reverse). Each pair of primers was shown to yield only one product. The Q-PCR parameters consisted of an initial hold at $95^{\circ} \mathrm{C}$ for $5 \mathrm{~min}$ followed by 35 cycles of $95^{\circ} \mathrm{C}$ for $30 \mathrm{~s}, 54.5^{\circ} \mathrm{C}$ (caspase-7) or $56^{\circ} \mathrm{C}$ ( $\beta$-actin) for $30 \mathrm{~s}$ and $72^{\circ} \mathrm{C}$ for $30 \mathrm{~s}$. After each Q-PCR run, a melting curve was performed to ensure that only a single amplicon was generated. Caspase-7 mRNA levels were normalized to control values of $\beta$-actin (\%).

\section{Detection of MMP-9 secretion}

The SW620 cells were seeded at $1 \times 10^{6}$ cells $/ \mathrm{mL}$ into 6 -well plates and serum-starved for $16 \mathrm{~h}$ prior to stimulation with PAR2-AP $(100 \mu \mathrm{mol} / \mathrm{L})$ or factor VIIa $(10 \mathrm{nmol} / \mathrm{L})$ for $24 \mathrm{~h}$. The cells in some wells were pretreated with EGCG (100 $\mu \mathrm{g} / \mathrm{mL}$ ) for $15 \mathrm{~min}$. The MMP-9 secreted into the cell supernatant was measured using MMP-9 ELISA assay kits following the manufacturer's instructions. The MMP-9 protein level was expressed as $\mathrm{ng} / \mathrm{mL}$.

\section{TF activity measurement}

The SW620 cells were seeded at $1 \times 10^{6}$ cells $/ \mathrm{mL}$ into 6-well plates and treated as described above. Following stimulation, the cells were briefly trypsinized, suspended in Leibovitz's L-15/10\% FBS, pelleted, and resuspended in Tris-buffered saline (TBS) at a density of $10^{6}$ cells $/ \mathrm{mL}$. The cells were then pelleted again and lysed with $1 \mathrm{~mL}$ of lysate buffer (TBS/1\% Triton X-100/1 mmol/L PMSF). The TF activity of the lysates was determined based on factor $\mathrm{X}$ activation by the TF/factor VIIa complex, and the resulting factor Xa was measured using a chromogenic assay (Actichrome ${ }^{\mathrm{TM}} \mathrm{TF}$ provided by ADI).

\section{Western blotting analysis}

For detection of NF-kB (p65/RelA) protein expression, SW620 cells were seeded at $1 \times 10^{7}$ cells per well into $10-\mathrm{cm}$ plates and stimulated with PAR2-AP $(100 \mu \mathrm{mol} / \mathrm{L})$ or factor VIIa (10 $\mathrm{nmol} / \mathrm{L})$. The cells in some wells were pretreated with various concentrations of EGCG $(0,25,50,75$, and $100 \mu \mathrm{g} / \mathrm{mL})$ for $15 \mathrm{~min}$, and EGCG was not removed. Following the manufacturer's protocol, nuclear proteins were accumulated. To assay the protein levels of phospho-ERK1/2 and caspase-7, SW620 cells $\left(1 \times 10^{6}\right)$ were seeded into 6-well plates and treated as above, followed by preparation of cell lysates. The protein concentrations of the samples were measured using a spectrophotometer (Thermo Scientific, USA). Sodium dodecyl sulfate (SDS)-polyacrylamide gel electrophoresis (PAGE) was used to separate $30 \mu \mathrm{g}$ of protein per well, and the bands were transferred to PVDF membranes (Bio-Rad, CA, USA). The membranes were blocked with a blocking solution containing $5 \%$ defatted milk/Tris-buffered saline/ $0.05 \%$ Tween-20 (TBST) ( $\mathrm{pH}$ 7.6) for $1 \mathrm{~h}$ at room temperature (RT). After being washed 3 times with TBST, the membranes were probed with anti-NF-kB (p65/RelA, 1:1000), anti-caspase-7 (1:1000), antiphospho-ERK1/2 (1:1000), anti-total-ERK1/2 (1:1000), anti$\beta$-actin (1:2500) or anti-histone H3 (1:500) antibodies with gentle agitation overnight $(16 \mathrm{~h})$ at $4{ }^{\circ} \mathrm{C}$. The membrane was then washed with TBST three times and incubated for $1 \mathrm{~h}$ at RT with horseradish peroxidase (HRP)-conjugated secondary antibodies (1:2000, Cell Signaling Technology, Billerica, MA, USA). Finally, immunoreactive proteins were visualized using ECL Western blotting detection reagents (GE Healthcare, Buckinghamshire, UK) and quantitated using a Bio-Rad Fluor-S Multi Imager (Typhoon 9400, Amersham, Sweden).

\section{Statistical analysis}

The data were expressed as mean \pm SEM. The statistical significance of the differences was calculated by applying analysis of variance (ANOVA) using SPSS software (version 16.0). $P<0.05$ was considered statistically significant.

\section{Results}

EGCG inhibits PAR2-AP- or factor VIla-induced proliferation and migration of SW620 cells

Our previous work indicated that PAR2-AP $(100 \mu \mathrm{mol} / \mathrm{L})$ and factor VIIa $(10 \mathrm{nmol} / \mathrm{L})$ promoted SW620 cell proliferation and migration ${ }^{[9]}$. In this study, we first investigated whether EGCG at various concentrations could decrease the effects of PAR2$\mathrm{AP}$ and factor VIIa on cell proliferation (as assayed using the MTT reagent). As shown in Figure 1A, EGCG inhibited PAR2AP- $(100 \mu \mathrm{mol} / \mathrm{L})$ or factor VIIa- $(10 \mathrm{nmol} / \mathrm{L})$ induced growth
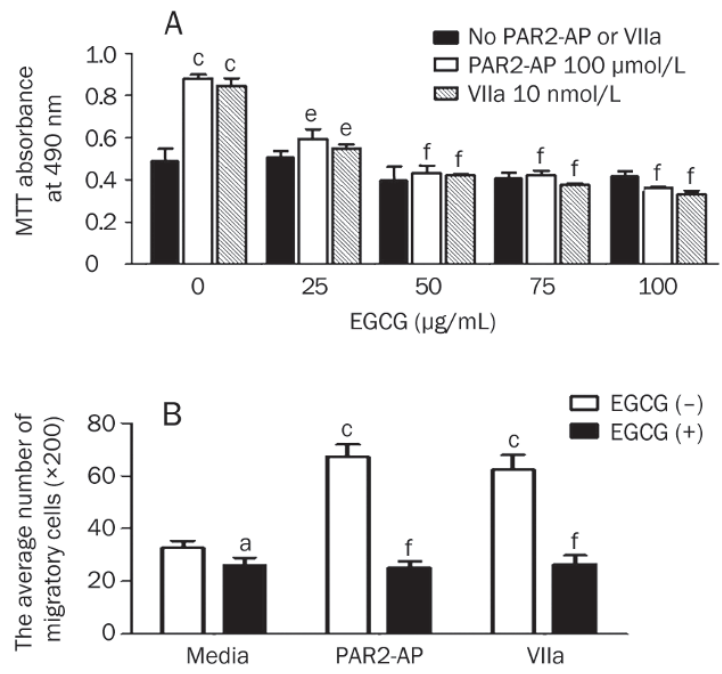

Figure 1. Effects of EGCG on PAR2-AP- and factor VIla-induced proliferation and migration of SW620 cells. (A) SW620 cells were plated at $5 \times 10^{4}$ cells in 96 -well plates and pretreated with different concentrations of EGCG $(0,25,50,75$, and $100 \mu \mathrm{g} / \mathrm{mL})$ for $15 \mathrm{~min}$, then incubated with PAR2-AP $(100 \mu \mathrm{mol} / \mathrm{L})$ or factor VIla $(10 \mathrm{nmol} / \mathrm{L})$ for $24 \mathrm{~h}$. The above EGCG was kept in media. The cell proliferation was measured using MTT colorimetric assay. $n=6$. Mean \pm SEM. ${ }^{e} P<0.05,{ }^{f} P<0.01$ vs PAR2-AP- or factor VIla-stimulated alone. (B) The cells were pretreated with or without EGCG $(100 \mu \mathrm{g} / \mathrm{mL})$ for $15 \mathrm{~min}$ as described above and then incubated with PAR2-AP $(100 \mu \mathrm{mol} / \mathrm{L})$ or factor VIla $(10 \mathrm{nmol} / \mathrm{L})$ for $8 \mathrm{~h}$. The cell migratory potential was measured by modified Boyden Chambers as described in Methods. $n=3$. Mean \pm SEM. ${ }^{a} P>0.05,{ }^{c} P<0.01$ vs media only; ${ }^{e} P<0.05,{ }^{f} P<0.01$ vs PAR2-AP- or factor VIla-stimulated alone. 
of SW620 cells. The inhibitory effects of EGCG were shown at concentrations as low as $25 \mu \mathrm{g} / \mathrm{mL}$, with the maximal effects observed at $50 \mu \mathrm{g} / \mathrm{mL}$ (approximately 60\% inhibition). Increasing the concentration of EGCG to 75 or $100 \mu \mathrm{g} / \mathrm{mL}$ did not further enhance its effects. In the absence of stimulation by PAR2-AP or factor VIIa, EGCG itself had no significant effects on the proliferation of cells. The inhibitory effects of EGCG were also confirmed with cell cycle analysis using flow cytometry, where a dose-dependent effect was observed from 25 to $100 \mu \mathrm{g} / \mathrm{mL}$ EGCG (Supplemental Figure 1). The difference between the dose effects observed in the MMT and cell cycle analyses may be due to different incubation times (24 h in MMT versus $8 \mathrm{~h}$ in the cell cycle analysis). EGCG itself was not toxic, based on a trypan blue exclusion assay (Supplemental Figure 2).

We next asked if EGCG was capable of inhibiting PAR2-APor factor VIIa-induced SW620 cell migration, as determined by Transwell chamber assays. The data showed that preincubation of cells with EGCG $(100 \mu \mathrm{g} / \mathrm{mL})$ prior to PAR2-AP $(100 \mu \mathrm{mol} / \mathrm{L})$ or factor VIIa $(10 \mathrm{nmol} / \mathrm{L})$ treatment resulted in decreases of $63 \%$ and $62 \%$ in the number of migratory cells, compared with the corresponding control (PAR2-AP or factor VIIa treatment without EGCG pre-treatment). EGCG alone had no significant effects on the migration of cells (Figure 1B) (cell migration images are shown in Supplemental Figure 3). These results demonstrated that EGCG inhibited both PAR2AP- and factor VIIa-mediated migration of SW620 cells.

\section{Effects of EGCG on the actin cytoskeleton in SW620 cells}

Phalloidin staining, which labels actin filaments, was used to assess changes in the cytoskeleton following PAR2-AP and factor VIIa treatment in the presence and absence of EGCG. The cytoskeleton of untreated cells was found to have some homogeneous actin fibers, which were stained a moderate red color (Figure 2A). However, after exposure to PAR2-AP (100 $\mu \mathrm{mol} / \mathrm{L})$ or factor VIIa $(10 \mathrm{nmol} / \mathrm{L})$ for $1 \mathrm{~h}$, the actin filaments were present at the cell cortex, in filopodia and pseudopodia and stained a strong red color (Figures 2B, 2C). Pre-treatment of cells with EGCG $(100 \mu \mathrm{g} / \mathrm{mL})$ significantly rescued the aberrant actin organization that was induced by PAR2-AP or factor VIIa (Figures 2E, 2F). EGCG alone had no effect on the actin cytoskeleton in SW620 cells (Figure 2D).

\section{Effects of EGCG on the expression of caspase-7 in SW620 cells}

Caspase-7 is one of the key effector caspases that induce cell apoptosis. In a previous study, we showed that caspase-7 was down-regulated by PAR2-AP or factor $\mathrm{VIIa}^{[9]}$. To examine whether EGCG could affect the regulatory effects of PAR2-AP or factor VIIa on caspase-7 expression in SW620 cells, the caspase-7 mRNA and protein levels in these cells were evaluated under different conditions. We found that both PAR2-AP (100 $\mu \mathrm{mol} / \mathrm{L})$ and factor VIIa $(10 \mathrm{nmol} / \mathrm{L})$ decreased the level of caspase-7 mRNA (Figure 3A, white column). However, preincubation of SW620 cells with EGCG $(100 \mu \mathrm{g} / \mathrm{mL})$ significantly increased caspase-7 mRNA expression, even though the cells were treated with similar concentrations of PAR2-AP and factor VIIa (Figure 3A, black column). Compared with the corresponding controls (PAR2-AP or factor VIIa treatment alone), EGCG increased caspase-7 mRNA levels to approximately 4.3and 4-fold (Figure 3A). Similarly, the caspase-7 protein level also increased with treatment of EGCG prior to PAR2-AP or factor VIIa stimulation (Figure 3B). EGCG alone had a slight effect on the regulation of caspase-7 release compared with media alone, but it was not statistically significant.

\section{Effects of EGCG on the expression of TF and MMP-9 in SW620 cells}

It has been shown that TF and MMP-9 are closely associated with tumor growth, invasion and metastasis ${ }^{[12,13]}$. Our previous data also showed that TF levels were elevated in SW620 cells stimulated with PAR2-AP or factor VIIa ${ }^{[9]}$. In this study, we found that both PAR2-AP $(100 \mu \mathrm{mol} / \mathrm{L})$ and factor VIIa (10 nmol/L) enhanced the expression of TF and MMP-9 (Figure $4 \mathrm{~A}$ and $4 \mathrm{~B}$, white column). When the cells were pre-incubated with EGCG $(100 \mu \mathrm{g} / \mathrm{mL})$, PAR2-AP- or factor VIIa-induced TF activity and MMP-9 expression were markedly decreased $(P<0.01$ vs PAR2-AP or factor VIIa alone), as shown in the black column in Figures 4A and 4B. EGCG alone seemed to
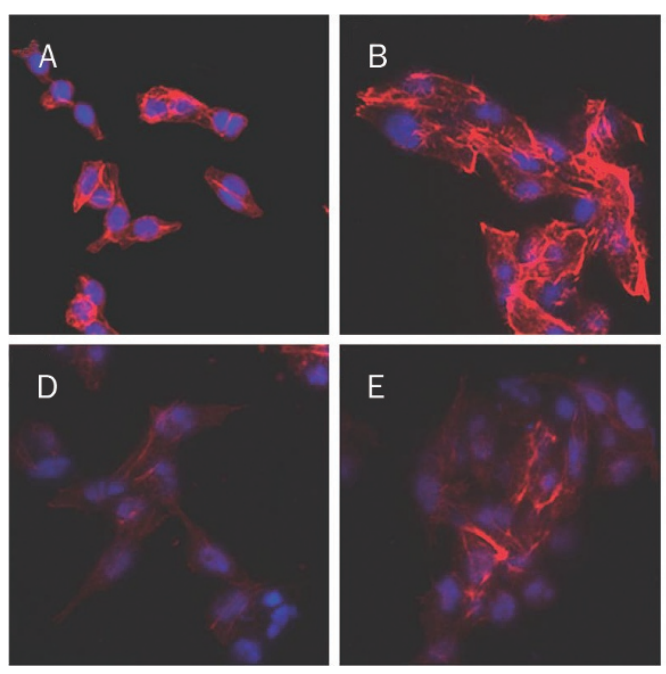
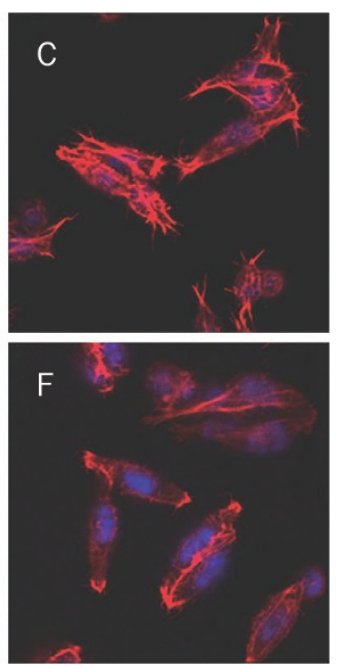

Figure 2. Fluorescence photomicrographs of SW620 cells with rhodamin-conjugated phalloidin and Hoechst 33342 staining ( $\times 400)$. SW620 cells were placed in 24 -well culture dishes at $3 \times 10^{4}$ cells/well and treated with different conditions for $1 \mathrm{~h}$. Then, the cells were fixed with $4 \%$ paraformaldehyde and washed with PBS three times. The DNA was stained with Hoechst 33342 (blue) and the actin cytoskeleton with rhodaminconjugated phalloidin (red) which were observed under a laser scanning confocal fluorescence microscope. (A) Media only; (B) With $100 \mu \mathrm{mol} / \mathrm{L}$ of PAR2-AP; (C) With $10 \mathrm{nmol} / \mathrm{L}$ of factor VIla; (D) With $100 \mu \mathrm{g} / \mathrm{mL}$ of EGCG; (E) With EGCG $(100 \mu \mathrm{g} / \mathrm{mL}) /$ PAR2-AP $(100 \mu \mathrm{mol} / \mathrm{L})$; (F) With EGCG $(100 \mu \mathrm{g} / \mathrm{mL}) /$ factor VIla $(10 \mathrm{nmol} / \mathrm{L})$. 


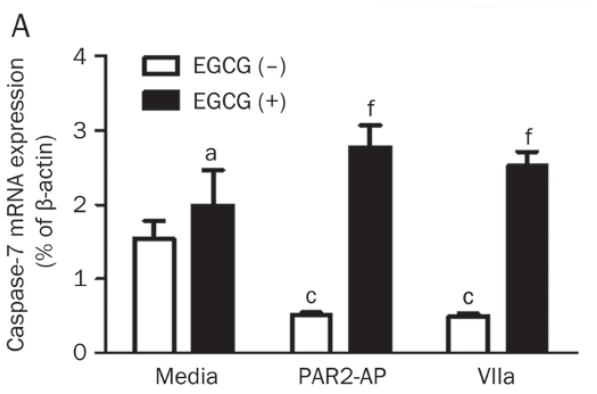

B
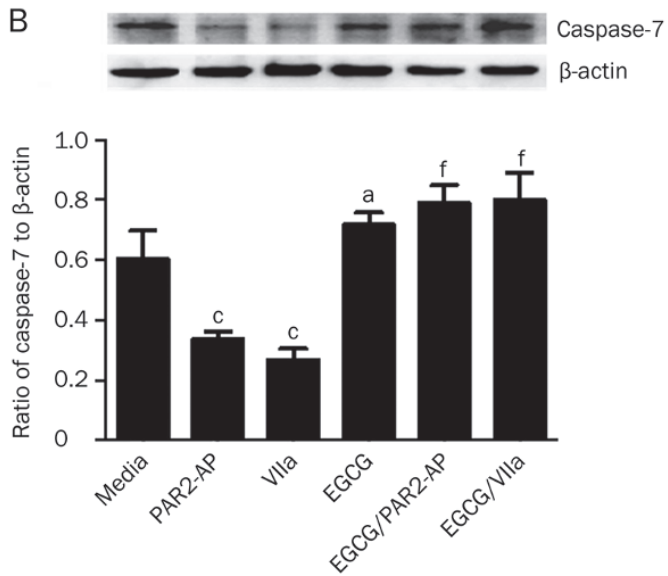

Figure 3. Effects of EGCG on caspase-7 expression in SW620 cells. SW620 cells $\left(1 \times 10^{6}-1 \times 10^{7}\right)$ were stimulated with PAR2-AP $(100 \mu \mathrm{mol} / \mathrm{L})$ or factor VIla $(10 \mathrm{nmol} / \mathrm{L})$ in the absence or presence of EGCG $(100 \mu \mathrm{g} /$ $\mathrm{mL})$ for $2 \mathrm{~h}$ or $24 \mathrm{~h}$. Then the total RNAs $(2 \mathrm{~h})$ and cell lysates $(24 \mathrm{~h})$ were collected for caspase-7 mRNA (A) and its protein (B) determination using QT-PCR and Western blot analysis, respectively. The caspase-7 mRNA levels were normalized to control values of $\beta$-actin and its protein levels were expressed as the ratio of caspase- $7 / \beta$-actin bands density. $n=3$. Mean \pm SEM. ${ }^{\mathrm{a}} P>0.05,{ }^{\mathrm{c}} P<0.01$ vs media only; ${ }^{\mathrm{f}} P<0.01$ vs PAR2-AP- or factor VIla-stimulated alone.

have a slight inhibitory effect on the MMP-9 level $(P<0.05$ vs media only).

\section{Effects of EGCG on activation of ERK1/2 and NF-KB in SW620 cells}

Previously, we found that PAR2-AP and factor VIIa stimulated the activation of ERK1/2 and NF-KB (p65/RelA) in SW620 cells within 30 min of treatment ${ }^{[14,15]}$. In this study, we further investigated whether EGCG could influence the effects of PAR2-AP and factor VIIa on the levels of p-ERK1/2 and NF-kB (p65/RelA) in the cells. As the concentrations of EGCG increased $(0-100 \mu \mathrm{g} / \mathrm{mL}$ ), the levels of p-ERK1/2 (Figure 5A) and NF-kB (p65/RelA) (Figure 5B) in SW620 cells stimulated with factor VIIa $(10 \mathrm{nmol} / \mathrm{L})$ gradually decreased, indicating a dose-dependent inhibitory effect of EGCG. Similarly, the stimulatory effects of PAR2-AP $(100 \mu \mathrm{mol} / \mathrm{L})$ on p-ERK1/2 and NF-kB (p65/RelA) were also blocked by EGCG (100 $\mu \mathrm{g} / \mathrm{mL})$.
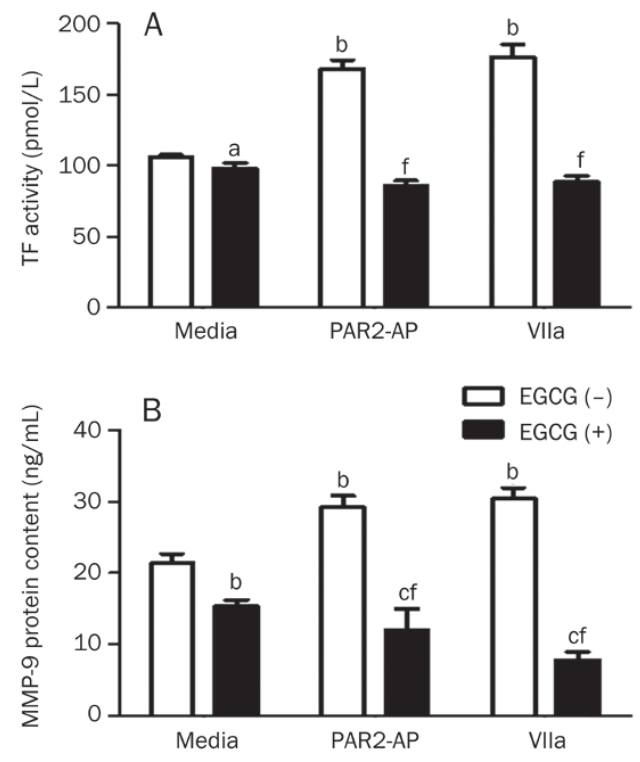

Figure 4. Effect of EGCG on the expression of TF and MMP-9 in SW620 cells. The cells $\left(1 \times 10^{6}\right)$ were incubated with PAR2-AP $(100 \mu \mathrm{mol} / \mathrm{L})$ or factor VIla $(10 \mathrm{nmol} / \mathrm{L})$ in the absence or presence of EGCG $(100 \mu \mathrm{g} / \mathrm{L})$ for $24 \mathrm{~h}$. The cell lysates were prepared and the TF activity (A) as well as MMP-9 levels (B) was measured by the specific kits, respectively. $n=3$. Mean \pm SEM. ${ }^{\mathrm{a}} P>0.05,{ }^{\mathrm{b}} P<0.05,{ }^{\mathrm{c}} P<0.01$ vs media only; ${ }^{\mathrm{f}} P<0.01$ vs PAR2AP- or factor VIla-stimulated alone.

\section{Discussion}

It is well known that factor VII can bind to TF on the cell surface and then activated by cleavage to generate factor VIIa. The formation of the TF/factor VIIa complex triggers the blood coagulation cascade. As a trypsin-like serine protease, factor VIIa by itself or in the TF/factor VIIa complex can trigger the cell signal transduction pathway in certain cells. It has been reported that factor VIIa or TF/factor VIIa might activate other receptors on the cell surface and cause a series of changes within the cell ${ }^{[16]}$. It was found that PAR2 was activated by factor VIIa and that TF/factor VIIa/PAR2 was involved in tumor growth and invasion in colorectal cancer and breast carcinoma. We previously demonstrated that both TF and PAR2 are highly expressed in the colon cancer cell line SW620. Factor VIIa can activate PAR2 and promote SW620 cell proliferation and migration in a TF-dependent manner. Some intracellular signaling molecules, such as ERK1/2 and NF- $\mathrm{KB}$, are activated in these processes ${ }^{[9,14,15]}$.

The anti-tumor properties of EGCG have received much attention in recent years. It has been shown that EGCG can induce apoptosis and inhibit proliferation in many tumor cell lines. Recent studies revealed that EGCG modulates the cell signaling pathways associated with angiogenesis, metastasis, and migration of prostate, liver and breast cancer cells ${ }^{[17]}$. Lim et al found that EGCG effectively inhibited HGF-induced invasion and metastasis of hypopharyngeal carcinoma cells via several intracellular signaling pathways ${ }^{[18]}$. In the current study, we investigated whether EGCG was able to interfere 

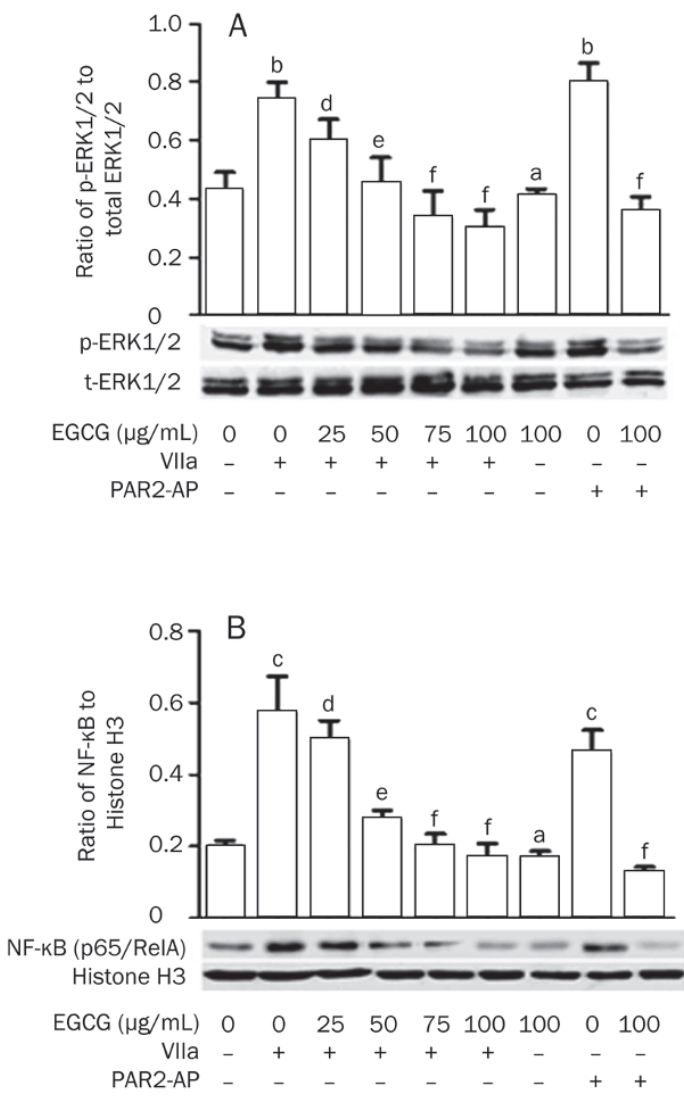

Figure 5. Effects of EGCG on activation of ERK1/2 and NF-KB pathway in SW620 cells. The cells were pretreated with or without the indicated concentrations of EGCG for $15 \mathrm{~min}$ and then incubated with PAR2-AP $(100 \mu \mathrm{mol} / \mathrm{L})$ or factor VIla $(10 \mathrm{nmol} / \mathrm{L})$ for indicated time. The above EGCG was kept in media. The cytoplasmic and nuclear lysates of the cells were collected and subjected to Western analysis with antibodies to total and phosphorylated ERK1/2 (A) and to NF-KB/p65 as well as Histon H3 (B). $n=3$. Mean \pm SEM. ${ }^{a} P>0.05,{ }^{b} P<0.05,{ }^{c} P<0.01$ vs control; ${ }^{d} P>0.05$, ${ }^{\mathrm{e}} P<0.05,{ }^{\mathrm{f}} P<0.01$ vs PAR2-AP- or factor VIla-stimulated alone.

with the effects of the TF/factor VIIa/PAR2 axis on SW620 cells.

Our results showed that PAR2 agonist- (PAR2-AP) or factor VIIa-induced SW620 cell proliferation was inhibited in a dose-dependent manner by EGCG. At a concentration of 100 $\mu \mathrm{g} / \mathrm{mL}$, EGCG decreased the number of migratory cells that were stimulated by PAR2-AP or factor VIIa by approximately $63 \%$ or $62 \%$, respectively (Figure 1). These inhibitory effects of EGCG on PAR2-AP- and factor VIIa-induced proliferation and migration of SW620 cells led us to explore the changes in the actin cytoskeleton and to determine if these changes were closely associated with cell adhesion, invasion and signal transduction ${ }^{[19]}$. Indeed, both PAR2-AP and factor VIIa induced cytoskeleton reorganization, as indicated by increased filopodia and pseudopodia, and EGCG prevented this change. This result may partly elucidate the mechanism(s) of EGCGmediated effects on cell proliferation and migration.

Caspase-7 has been defined as one of the key executioners involved in apoptosis induced by various stimuli, and it is nec- essary for apoptosis-associated nuclear changes, such as chromatin condensation ${ }^{[20]}$. It has been demonstrated that EGCG can mediate the activation of caspases by inhibition of the NF-KB pathway and subsequently induce apoptosis in human epidermoid carcinoma A431 cells ${ }^{[21]}$. In our present study, we further demonstrated that activation of PAR2 in SW620 cells by PAR2-AP or factor VIIa suppressed caspase-7 expression at both the mRNA and protein levels. EGCG reversed the downregulating effects of PAR2-AP or factor VIIa on the expression of caspase-7 (Figure 3). These results suggested that EGCG might enhance cell apoptosis and thereby reduce cell proliferation. Whether EGCG can affect the expression of other molecules related to cell apoptosis (such as caspase-3) remains to be answered.

Over the past few years, several target molecules, including angiogenic growth factor, chemotactic factors, and some antiapoptotic molecules, were found to be regulated by the activation of the TF/factor VIIa/PAR2 complex. Furthermore, TF has been implicated in angiogenesis, growth and metastasis of cancers $^{[22]}$. Matrix metalloproteinases (MMPs) are closely related to cell invasion and migration. Our data shows that EGCG significantly suppressed both TF activity and MMP-9 secretion in SW620 cells induced by PAR2 activation with PAR2-AP or factor VIIa stimulation. These results are largely consistent with other reports. For example, Annabi et al demonstrated that EGCG directly and indirectly decreased MMP-9 secretion in macrophage-like HL-60 cells $^{[23]}$. Lim et al showed that EGCG was able to inhibit the HGF-induced MMP-9 activity in hypopharyngeal carcinoma cells ${ }^{[18]}$. Taken together, these results suggest that EGCG is capable of blocking the expression of some key molecules in tumor cells and, therefore, it contributes to the suppression of cell proliferation, migration and metastasis.

It is well known that the ERK1/2 and NF-KB signaling pathways play a pivotal role in many cellular processes, such as proliferation, apoptosis, and differentiation ${ }^{[24-27]}$. PAR2 activation induced by the TF/factor VIIa complex can trigger cell signal transduction through different pathways, including ERK1/2 and NF-KB ${ }^{[15,28]}$. This study investigated whether EGCG could reverse the activation of ERK-1/2 as well as NF-KB by PAR2 activation. As shown in Figure 5, PAR2-AP, and factor VIIa activated ERK-1/2, as indicated by increased ERK-1/2 phosphorylation and NF-kB (p65/RelA) expression in the nuclear fraction. However, EGCG dose-dependently inhibited both ERK-1/2 and NF-kB activation by factor VIIa. Similarly, EGCG at a concentration of $100 \mu \mathrm{g} / \mathrm{mL}$ obviously inhibited PAR2-AP-induced ERK-1/2 and NF-KB activation. These results indicate that the blockade of ERK-1/2 and NF-KB activation is the major mechanism for the inhibitory effects of EGCG on TF/factor VIIa/PAR2 axis-mediated cell proliferation and migration.

In summary, the present data, together with our previous studies, strongly indicate that PAR2 activation by PAR2-AP or the TF/factor VIIa complex triggers the phosphorylation of ERK1/2 and the activation of the NF-KB signaling pathway, thereby regulating the expression of caspase- $7, \mathrm{TF}$, and 
MMP-9, which further contributes to the proliferation and migration of colon cancer cells. EGCG, the major polyphenolic constituent in green tea, can target the axis of TF/factor VIIa/ PAR2 and the ERK1/2/NF-KB signaling pathways and may serve as a preventive and therapeutic agent for colon cancers.

\section{Acknowledgements}

This project was supported by the Provincial Science Foundation of Jiangsu (No BK2010336) and the Student's Scientific Research of Jiangsu University (№ 09A080).

\section{Author contribution}

Hong ZHOU designed the research; Fang ZHOU performed the research and analyzed the data; Ting WANG and Ying WU contributed new reagents; Dong-lin GUO and Xian-mei ZHANG contributed to the experiments; Yuan MU and Biao WU contributed analytic tools; and Fang ZHOU and Hong ZHOU wrote the paper.

\section{Supplementary information}

Supplementary tables are available at Acta Pharmacologica Sinica website of NPG.

\section{References}

1 Rak J, Milsom C, Magnus N, Yu J. Tissue factor in tumour progression. Best Pract Res Clin Haematol 2009; 22: 71-83.

2 Khorana AA, Ahrendt SA, Ryan CK, Francis CW, Hruban RH, Hu YC, et al. Tissue factor expression, angiogenesis, and thrombosis in pancreatic cancer. Clin Cancer Res 2007; 13: 2870-5.

3 Petersen LC. Microarray studies of factor VIla-activated cancer cells. Thromb Res 2008; 122: S11-3.

4 Krishnan R, Kotian PL, Chand P, Bantia S, Rowland S, Babu YS. Probing the S2 site of factor VIla to generate potent and selective inhibitors: the structure of BCX-3607 in complex with tissue factorfactor VIla. Acta Crystallogr D Biol Crystallogr 2007; 63: 689-97.

5 Morris DR, Ding Y, Ricks TK, Gullapalli A, Wolfe BL, Trejo J. Proteaseactivated receptor-2 is essential for factor VIla and Xa-induced signaling, migration, and invasion of breast cancer cells. Cancer Res 2006; 66: 307-14.

6 Zerbib P, Grimonprez A, Corseaux D, Mouquet F, Nunes B, Petersen LC, et al. Inhibition of tissue factor-factor VIla proteolytic activity blunts hepatic metastasis in colorectal cancer. J Surg Res 2009; 153: $239-45$.

7 Kirkland JG, Cottrell GS, Bunnett NW, Corvera CU. Agonists of protease-activated receptors 1 and 2 stimulate electrolyte secretion from mouse gallbladder. Am J Physiol Gastrointest Liver Physiol 2007; 293: G335-46.

8 Zhou H, Hu H, Shi W, Ling S, Wang T, Wang H. The expression and the functional roles of tissue factor and protease-activated receptor-2 on SW620 cells. Oncol Rep 2008; 20: 1069-76.

9 Zhou H, Shi W, Zhou B, Guo D, Wang T. Tissue factor-factor VIla regulates interleukin-8, tissue factor and caspase-7 expression in SW620 cells through protease-activated receptor-2 activation. Mol Med Rep 2010; 3: 269-74.

10 Khan N, Mukhtar H. Multitargeted therapy of cancer by green tea polyphenols. Cancer Lett 2008; 269: 269-80.

11 Yamauchi R, Sasaki K, Yoshida K. Identification of epigallocatechin3 -gallate in green tea polyphenols as a potent inducer of p53- dependent apoptosis in the human lung cancer cell line A549. Toxicol In Vitro 2009; 23: 834-9.

12 Versteeg HH, Schaffner F, Kerver M, Petersen HH, Ahamed J, FeldingHarbermann B, et al. Inhibition of tissue factor signaling suppresses tumor growth. Blood 2008; 111: 190-9.

13 Ou YQ, Chen LH, Li XJ, Lin ZB, Li WD. Sinomenine influences capacity for invasion and migration in activated human monocytic THP-1 cells by inhibiting the expression of MMP-2, MMP-9, and CD147. Acta Pharmacol Sin 2009; 30: 435-41.

14 Zhou B, Zhou H, Ling S, Guo D, Yan Y, Zhou F, et al. Activation of PAR2 or/and TLR4 promotes SW620 cell proliferation and migration via phosphorylation of ERK1/2. Oncol Rep 2011; 25: 503-11.

15 Guo D, Zhou H, Wu Y, Zhou F, Xu G, Wen H, et al. Involvement of ERK1/2/NF-KB signal transduction pathway in TF/FVIla/PAR2-induced proliferation and migration of colon cancer cell SW620. Tumor Biol 2011; 32: 921-30.

16 Albrektsen T, Sørensen BB, Hjortø GM, Fleckner J, Rao LVM, Petersen LC. Transcriptional program induced by factor VIla-tissue factor, PAR1 and PAR2 in MDA-MB-231 cells. J Thromb Haemost 2007; 5: 158897.

17 Yang CS, Wang X, Lu G, Picinich SC. Cancer prevention by tea: animal studies, molecular mechanisms and human relevance. Nat Rev Cancer 2009; 9: 429-39.

18 Lim YC, Park HY, Hwang HS, Kang SU, Pyun JH, Lee MH, et al. Epigallocatechin-3-gallate (EGCG) inhibits HGF-induced invasion and metastasis in hypopharyngeal carcinoma cells. Cancer Lett 2008; 271: $140-52$.

19 Houben F, Ramaekers FC, Snoeckx LH, Broers JL. Role of nuclear lamina-cytoskeleton interactions in the maintenance of cellular strength. Biochim Biophys Acta 2007; 1773: 675-86.

20 Walsh JG, Cullen SP, Sheridan C, Lüthi AU, Gerner C, Martin SJ. Executioner caspase-3 and caspase-7 are functionally distinct proteases. Proc Natl Acad Sci U S A 2008; 105: 12815-9.

21 Gupta S, Hastak K, Afaq K, Ahmad N, Mukhtar H. Essential role of caspases in epigallocatechin-3-gallate-mediated inhibition of nuclear factor kappaB and induction of apoptosis. Oncogene 2004; 23 : 2507-22.

22 Belting M, Ahamed J, Ruf W. Signaling of the tissue factor coagulation pathway in angiogenesis and cancer. Arterioscler Thromb Vasc Biol 2005; 25: 1545-50.

23 Annabi B, Currie JC, Moghrabi A, B'eliveau R. Inhibition of HuR and MMP-9 expression in macrophage-differentiated HL-60 myeloid leukemia cells by green tea polyphenol EGCG. Leuk Res 2007; 31: 1277-84.

24 Chen $\mathrm{Y}$, Wang J, Yao $\mathrm{Y}$, Yuan W, Kong M, Lin Y, et al. CRP regulates the expression and activity of tissue factor as well as tissue factor pathway inhibitor via NF-kappaB and ERK 1/2 MAPK pathway. FEBS Lett 2009; 583: 2811-8.

25 Balmanno K, Cook SJ. Tumour cell survival signalling by the ERK1/2 pathway. Cell Death Differ 2009; 16: 368-77.

26 Lee YK, Ng KM, Lai WH, Man C, Lieu DK, Lau CP, et al. Ouabain facilitates cardiac differentiation of mouse embryonic stem cells through ERK1/2 pathway. Acta Pharmacol Sin 2011; 32: 52-61.

27 Wang S, Liu Z, Wang L, Zhang X. NF-kappB signaling pathway, inflammation and colorectal cancer. Cell Mol Immunol 2009; 6: 327 34.

28 Awasthi V, Mandal SK, Papanna V, Rao LV, Pendurthi UR. Modulation of tissue factor-factor VIla signaling by lipid rafts and caveolae. Arterioscler Thromb Vasc Biol 2007; 27: 1447-55. 